\title{
Hydrolysis of sheep's milk whey concentrate by membrane and evaluation of the antioxidant and antimicrobial properties
}

\author{
Hidrólise de concentrado de soro de leite de ovelha por membrana e avaliação das propriedades \\ antioxidantes e antimicrobianas \\ D. Preci ${ }^{1}$; I. A. Fernandes ${ }^{1}$; E. Valduga ${ }^{1}$; R. L. Cansian ${ }^{1}$; J. Steffens ${ }^{1 *}$; C. \\ Steffens ${ }^{1}$; V. B. Brião ${ }^{2}$ \\ ${ }^{1}$ Food Engineering Department, URI, Av. Sete de Setembro 1621, 99709-910, Erechim, Brazil \\ ${ }^{2}$ Food Engineering Department, University of Passo Fundo, BR-285, s/n., 99052-900, Passo Fundo, Brazil \\ *julisteffens@uricer.edu.br \\ (Recebido em 26 de novembro de 2020; aceito em 11 de fevereiro de 2021)
}

\begin{abstract}
Sheep's milk whey is an important source of protein and present functional properties. Studies related to the concentration of sheep's milk whey proteins are still scarce in the literature. In order to improve not only the chemical, physical and functional properties of foods, but also the absorption characteristics of the proteins, without impairing the nutritional value, enzymatic hydrolysis process can be used. From the hydrolysis of whey proteins are generated bioactive peptides that have antioxidant and microbial activity. The aim of this study was to produce sheep's milk whey concentrate by ultrafiltration/diafiltration process and to perform the enzymatic hydrolysis using corolase $\mathrm{H}-\mathrm{pH}$ in different times $(1,2,3,4,5$ and $6 \mathrm{~h})$ and evaluate the degree of hydrolysis, antioxidant and antimicrobial potential and protein fractions. The protein value found for diafiltered sheep's milk whey was $84 \%$ with protein fractions corresponded to $\beta$-lactoglobulin, $\alpha$-lactalbumin. The values of degree of hydrolysis were 12.07 and $15.55 \%$ in the evaluated times. The highest antimicrobial activity was observed in $1 \mathrm{~h}$ for Salmonella choleraesuise and Listeria monocytogenes and the high antioxidant activity was obtained for the maximum concentration tested $(3.0 \mathrm{mg} \mathrm{mL} / \mathrm{L})$ in $6 \mathrm{~h}$ of hydrolysis. Therefore the diafiltered sheep's milk whey hydrolysed presented antimicrobial and antioxidant characteristics, presenting potential of application in foods.
\end{abstract}

Keywords: diafiltration, Salmonella choleraesuise, Listeria monocytogenes

O soro de leite de ovelha é uma importante fonte proteica e apresenta propriedades funcionais. Estudos relacionados à concentração de proteínas do soro de leite de ovelha ainda são escassos na literatura. Para melhorar não só as propriedades químicas, físicas e funcionais dos alimentos, mas também as características de absorção das proteínas, sem comprometer o valor nutricional, pode-se utilizar o processo de hidrólise enzimática. A partir da hidrólise das proteínas do soro de leite são gerados peptídeos bioativos que possuem atividade antioxidante e microbiana. O objetivo deste estudo foi produzir concentrado de soro de leite de ovelha por ultrafiltração/diafiltração e realizar a hidrólise enzimática utilizando corolase $\mathrm{H}$-pH em diferentes tempos $(1,2,3,4,5$ e $6 \mathrm{~h})$ e avaliar o grau de hidrólise, potencial antioxidante e antimicrobiano e frações protéicas. O valor proteico encontrado para o soro de leite de ovelha diafiltrado foi de $84 \%$ com as frações protéicas correspondendo a $\beta$-lactoglobulina, $\alpha$-lactalbumina. Os valores do grau de hidrólise foram 12,07 e $15,55 \%$ nos tempos avaliados. A maior atividade antimicrobiana foi observada em $1 \mathrm{~h}$ para Salmonella choleraesuise e Listeria monocytogenes e a alta atividade antioxidante foi obtida para a concentração máxima testada $(3,0 \mathrm{mg} \mathrm{mL} / \mathrm{L})$ em $6 \mathrm{~h}$ de hidrólise. Portanto, o soro de leite de ovelha diafiltrado hidrolisado apresentou características antimicrobianas e antioxidantes, apresentando potencial de aplicação em alimentos.

Palavras-chave: diafiltração, Salmonella choleraesuise, Listeria monocytogenes

\section{INTRODUCTION}

Milk whey is considered an important source of protein and present functional properties [1]. The proteins found in milk whey represent around $20 \%$ of the total proteins found in milk. Among the whey proteins, $\beta$-lactoglobulin $(\beta-\mathrm{Lg})$ is present in a greater amount than $\alpha$-lactalbumin $(\alpha-\mathrm{La})$, which are present in the range of $45-57 \%$ and $15-25 \%$, respectively. These proteins represent about $70 \%$ of the total proteins present in whey, and are mainly responsible for the capacity of emulsion formation, foam, gelation and hydration capacity, being of great importance for foods [2]. 
However, one of the factors that hinder the whey utilization is the large amount of water, salts and lactose. One of the conventionally concentration methods is evaporation, which has the disadvantage of application of heat treatment, which in addition to high energy expenditure, generates concentrates with high salts and sugars contents. Therefore, an alternative method for concentration is the use of ultrafiltration (UF), which does not involve heat and phase change.

UF can be used for protein concentration, and reduction of lactose, salt and whey water contents, since the latter permeate the membrane $[3,4]$. To promote a more efficient removal of lactose and salts (molar mass below the membrane pore size) and higher protein concentration, can be used diafiltration (DF) [5]. This process consists in the addition of water to the UF concentrate, and can increase the whey protein content by $60-80 \%$.

Studies related to the concentration of sheep's milk whey proteins are still scarce in the literature. Sheep's milk whey has higher protein content than bovine milk whey [6]. In order to improve not only the chemical, physical and functional properties of foods, but also the absorption characteristics of the proteins, without impairing the nutritional value, enzymatic hydrolysis process can be used. From the hydrolysis of whey proteins are generated bioactive peptides that have antioxidant and microbial activity.

In this context, the aim of the present study was to concentrate sheep's milk whey by ultrafiltration/diafiltration and to evaluate the chemical characteristics. Also, to perform the enzymatic hydrolysis using corolase H-pH in different times with sheep's milk whey concentrate by DF and evaluate the degree of hydrolysis, antioxidant and antimicrobial potential and protein fractions.

\section{MATERIAL E METHODS}

The sheep's milk whey of Lacaune breed was obtained from the elaboration of colonial cheese, provided by the Gran Paladare Company, Chapecó, SC, Brazil. Sheep's milk whey was skimmed by a skimmer (Suck Milk) (fat $\cong 1 \%$ on a dry basis) and pasteurized at $75^{\circ} \mathrm{C}$ for $15 \mathrm{~s}$ in a pasteurizer plate (Sotronic), cooled to $4^{\circ} \mathrm{C}$ in a stainless-steel tank (Sotronic) and stored in a freezer at $2^{\circ} \mathrm{C}$.

Pasteurized skimmed sheep's milk whey (SMW) was subjected to ultrafiltration (UF) using polyamide membrane (Model 2538-K131-VYV -Koch Membrane Systems), spiral, 10kDa cut molecular mass, area $1.8 \mathrm{~m}^{2}$ and pressure $2.0 \mathrm{bar}$. For the whey concentration, were used $108 \mathrm{~L}$ of SMW. The volumetric concentration factor used was 8 , which was obtained by the ratio of the initial volume of the solution to the volume of the concentrate (or retentate).

The UF flow was obtained as follow:

$$
J p=\frac{V}{A . t}
$$

where $\mathrm{Jp}$ is the flow $\left(\mathrm{L} / \mathrm{m}^{2} \mathrm{~h}\right) ; \mathrm{A}$ is the membrane area $\left(\mathrm{m}^{2}\right) ; \mathrm{V}$ is the permeate volume $(\mathrm{L})$ and $\mathrm{t}$ is the permeation time $(\mathrm{h})$.

One liter of sheep's milk whey concentrate by UF (SMWUF) was frozen at $-80^{\circ} \mathrm{C}$ for $24 \mathrm{~h}$ in a vertical freezer (Consul, Brazil) packed in $200 \mathrm{~mL}$ glass vials. The samples were then dehydrated in a freeze drier (Module $4 \mathrm{~K}$ Freeze Dryer Edwars) at $-40^{\circ} \mathrm{C}$ for $48 \mathrm{~h}$ for further characterization. The SMWUF remainder was diafiltered (DF). 12.5 L of SMWUF were submitted to DF process under the same UF conditions, where $100 \mathrm{~L}$ of water high purity was added to the SMWUF and again $100 \mathrm{~L}$ were permeated. This procedure was repeated 3 times, where 3 wash cycles were performed using $100 \mathrm{~L}$ of water in each wash, ensuring that at the end of DF process were retained 12.5 L of sheep's milk whey concentrate by DF (SMWDF).

The flow of each DF cycle was named as: first wash (P1), second wash (P2) and third wash (P3) and calculated according to Equation 1. The SMWDF obtained after the third wash cycle was frozen at $-80^{\circ} \mathrm{C}$ and dehydrated in a lyophilizer (Edwards, England), at $-40^{\circ} \mathrm{C}$ for $48 \mathrm{~h}$, for further characterization and enzymatic hydrolysis.

To perform the enzymatic hydrolysis of SMWDF a commercial protease ( $\mathrm{pH}$ corolase $\mathrm{H}$ ) was used which was supplied by manufacturer $A B$ Enzymes, being an alkaline protease of fungal origin, 
produced by the filamentous fungus Trichoderma reesei with enzymatic activity of $482 \mathrm{U} / \mathrm{mL}$. The amount of enzyme used in this work was based on the minimum dosage indicated by the manufacturer which is $1 \%$ based on the protein content, $\mathrm{pH} 8$ and $60{ }^{\circ} \mathrm{C}$.

Enzymatic hydrolysis was performed in Erlenmeyer, containing hydrated solution (10\% of SMWDF) in an incubator shaker (New Brunswick Scientific C25, USA) at $60^{\circ} \mathrm{C}$ and $100 \mathrm{rpm}$. The pH was adjusted with $3 \mathrm{M} \mathrm{NaOH}$ (Sigma Aldrich, USA) to 8.0. Next, the enzyme was added for hydrolysis reaction. The degree of hydrolysis was evaluated according to the method of Hoyle and Merritt (1994) [7], at different reaction times (1, 2, 3, 4, 5, and $6 \mathrm{~h})$. After hydrolysis reactions times, the enzyme was inactivated by heating at $90^{\circ} \mathrm{C}$ for $10 \mathrm{~min}$ in a water bath (Quimis, model 0214M2, Brazil).The hydrolyzate was centrifuged (Kubota,Tokyo, Japan) at $9000 \mathrm{~g}$ for $30 \mathrm{~min}$. $20 \%$ trichloro acetic acid (TCA, Sygma Aldrich) in volume was added in the supernatant, next centrifuged (Kubota, Tokyo, Japan) at $6700 \mathrm{~g}$ at $10{ }^{\circ} \mathrm{C}$ for $20 \mathrm{~min}$, and collect $10 \%$ of soluble material. The degree of hydrolysis (DH) was obtained as follow:

$\% \mathrm{DH}=100 .(10 \% \mathrm{TCA}-$ soluble nitrogen in the sample /total nitrogen in the sample)

The soluble nitrogen of the sample was obtained according to Lowry et al. (1951) [8] method. The hydrolyzate of different hydrolysis times $(1,2,3,4,5$ and $6 \mathrm{~h})$ were evaluated in relation to antioxidant and antimicrobial potential and protein fractions.

The SMW, SMWUF and SMWDF samples were evaluated in relation to humidity, total solids, ash, protein, lipids, $\mathrm{pH}$, lactose, colour and conductivity. Humidity, total solids, ash and protein analysis were performed according to methodology described by AOAC (2007) [9]. The results were expressed in $\%$ on a dry weight basis.

Lipids were extracted with cold solvent mixture according to IDF/FIL (1986) [10]. The pH was determined with a digital potentiometer (Digimed, Model DM-22, Brazil). Lactose was obtained by the DNS method (3,5-dinitro salicylate) according to methodology of Miller (1959) [6]. Instrumental colour was determined using a colorimeter (Minolta, Model CR400, USA) with D65 light source, expressing the results in CIELAB colour space ( $\left.\mathrm{L}^{*} \mathrm{a}^{*} \mathrm{~b}^{*}\right)$. The electrical conductivity using a conductivity meter (Prolabmas, RS23, Indonesia)

The protein fractions of SMW, SMWUF and SMWDF and of hydrolyzate samples were determined in SDS-PAGE (sodium dodecyl sulfate-polyacrylamide gel electrophoresis). The molecular weight of the proteins was determined by the electrophoresis analysis following the Laemmli (1970) [11] methodology.

The antioxidant potential of the hydrolyzate samples was obtained by DPPH assay $(1,1-$ diphenyl-2-picrylhydrazyl) according to the method of Miranda and Fraga (2006) [12] with adaptations. The hydrolyzate samples $(500 \mu \mathrm{L})$ with concentrations of $0.5 ; 1.0 ; 1.5 ; 2.0$ and $3.0 \%$ in ethanol (Sygma Aldrich, USA) were incubated for $30 \mathrm{~min}$ with $500 \mu \mathrm{L}$ of $0.1 \mathrm{mM}$ DPPH. The standard solution was obtained replacing $500 \mu \mathrm{L}$ of hydrolyzate samples by $500 \mu \mathrm{L}$ of ethanol, without DPPH. Measurements of absorbance were performed at $517 \mathrm{~nm}$ in spectrophotometer (PróAnálise model UV1600). The capturing activity of the hydrolyzate samples was expressed as a DPPH inhibiting percentage. To establish the IC50 a regression analysis was performed, corresponding to the necessary quantity to capture $50 \%$ of the DPPH free radical.

Two bacterial strains were used to determine the hydrolyzate samples minimal bactericidal activity: Salmonella choleraesuis (ATCC 107008 - gram negative) and Listeria monocytogenes (ATCC 7644 - gram positive) derived from the American Type Culture Collection.

The minimal bactericidal concentration was measured in vitro according to methodology of Smith-Palmer et al. (1998) [13] with adaptations. Firstly, successive dilutions (20; 25; and 30\%) were done for hydrolyzate samples in LB medium. Next, $900 \mu \mathrm{L}$ of the diluted solution was inoculated using $100 \mu \mathrm{L}$ of the bacteria medium (108 UFC/mL). One control test has been done with only the inoculated bacteria, without any hydrolyzate sample. After homogenization during 10 min, $100 \mu \mathrm{L}$ were colleted, added to solidified Luria-Bertani Agar (LBA) medium and incubated in an oven (Fanem $-320-\mathrm{SE}$, Brazil) at $37^{\circ} \mathrm{C}$ for $24 \mathrm{~h}$.

The results obtained of the experiments were evaluated by variance analysis (ANOVA), followed by the Tukey and Student test, Pearson correlation using STATISTICA version 5.0 software, $95 \%$ reliability. 


\section{RESULTS AND DISCUSSION}

Flow of water and sheep's milk whey of UF and DF process are showed in Figure 1. In the UF step, the initial flow was $33 \mathrm{~L} / \mathrm{m}^{2} \mathrm{~h}$, reducing over time, reaching $18 \mathrm{~L} / \mathrm{m}^{2} \mathrm{~h}$ in the end of the process. This decrease occurs due to the formation of fouling and membrane polarization, caused especially by proteins and lipids [14]. This flow was smaller than water, because the water does not present solids that can difficult the permeation.

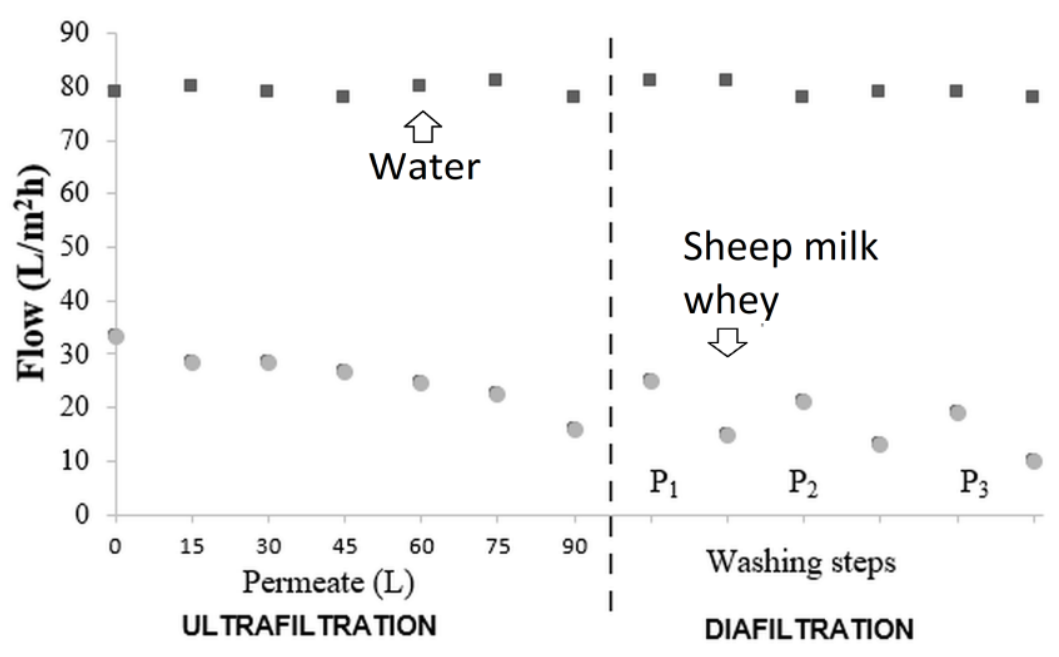

Figure 1: Flow for water and sheep's whey in the UF and DF process.

The initial flow of the first wash (P1) $27 \mathrm{~L} / \mathrm{m}^{2} \mathrm{~h}$, was higher in relation to the third wash (P3) 20 $\mathrm{L} / \mathrm{m}^{2} \mathrm{~h}$. This decrease is due to the addition of water in the DF that dilutes the concentrate, facilitating the passage through the membrane and also by the fouling and calcium ions deposition on the membrane, besides the interaction with proteins [15].

The results of SMW, SMWUF and SMWDF characterization are presented in Table 1. The SMW presented pH 6.14, considered a sweet milk whey according to Brasil (2013) [16]. It is not significant difference $(\mathrm{p}<0.05)$ between the $\mathrm{pH}$ values of SMW, SMWUF and SMWDF (Table 1).

Table 1: Values of $\mathrm{pH}$, conductivity, total solids, protein, lactose, lipids, ash and colour $L^{*} a^{*} b^{*}$.

\begin{tabular}{lccc}
\hline Analysis & SMW & SMWUF & SMWDF \\
\hline pH & $6.14^{\mathrm{a}} \pm 0.24$ & $6.17^{\mathrm{a}} \pm 0.21$ & $6.43^{\mathrm{a}} \pm 0.17$ \\
Conductivity $(\boldsymbol{\mu S} / \mathbf{c m})$ & $2083^{\mathrm{b}} \pm 4.77$ & $2357^{\mathrm{a}} \pm 5.77$ & $196.27^{\mathrm{c}} \pm 0.71$ \\
Total solids $(\boldsymbol{\%})$ & $6.69^{\mathrm{b}} \pm 0.02$ & $9.75^{\mathrm{a}} \pm 0.02$ & $4.94^{\mathrm{c}} \pm 0.04$ \\
Protein $^{\mathbf{1}}(\boldsymbol{\%})$ & $19.27^{\mathrm{c}} \pm 0.01$ & $40.94^{\mathrm{b}} \pm 0.08$ & $84.30^{\mathrm{a}} \pm 0.05$ \\
Lactose $^{\mathbf{1}}(\boldsymbol{\%})$ & $73.12^{\mathrm{a}} \pm 0.10$ & $53.96^{\mathrm{b}} \pm 2.01$ & $6.32^{\mathrm{c}} \pm 0.02$ \\
Lipids $^{\mathbf{1}}(\boldsymbol{\%})$ & $0.93^{\mathrm{c}} \pm 0.05$ & $1.81^{\mathrm{b}} \pm 0.07$ & $4.76^{\mathrm{a}} \pm 0.06$ \\
Ash $^{\mathbf{1}}(\boldsymbol{\%})$ & $7.24^{\mathrm{a}} \pm 0.07$ & $4.56^{\mathrm{b}} \pm 0.07$ & $0.48^{\mathrm{c}} \pm 0.11$ \\
Colour L* $^{*}$ & $38.85^{\mathrm{b}} \pm 0.04$ & $37.84^{\mathrm{c}} \pm 0.14$ & $42.12^{\mathrm{a}} \pm 0.19$ \\
Colour a* $_{\text {Colour b* }}^{*}$ & $-1.69^{\mathrm{b}} \pm 0.07$ & $-2.91^{\mathrm{c}} \pm 0.06$ & $-1.59^{\mathrm{a}} \pm 0.02$ \\
\hline
\end{tabular}

Means ( \pm standard deviations) followed by same letters on the lines, represents no significant difference at $5 \%$ level (Tukey test); ${ }^{1}$ Results expressed on dry matter.

L *: lightness or brightness, ranging from black $(0)$ to white (100), a *: chromaticity coordinate ranging from green (-) to red $(+)$, and $b *$ : coordinated chromaticity ranging from blue (-) to yellow (+).

The $\mathrm{L} *$ values refer to the brightness ranged from zero ( 0 - black) to one hundred (100-white) in the scale. The SMWDF showed high brightness and low total solids value, while the SMWUF presented low brightness and high total solids. Reductions in $\mathrm{L} *$ values can be attributed to the increase in the solids and consequently reductions in free water [17]. The colour $\mathrm{b} *$ in all samples 
presented positive values, indicating yellowish colour, because the colour $\mathrm{b} *$ varies from blue (negative) to yellow (positive). Azevedo et al. (2014) [18], claim that the presence of lactose and ash may contribute to the yellow coloration. This justifies the decrease of the intensity of yellow colour of SMWDF, since, in comparison with SMW and SMWUF presented the lowest values of lactose and ash, while SMWDF showed the highest intensity of yellow colour and also the highest values of lactose and ash. The colour a * ranges from green (negative) or red (positive). The SMWDF showed the highest green tonality in relation to the other samples, and also the highest total solids content. The SMWDF presented the lowest total solids content and less greenish colour than the other samples.

The lactose content decreased 26\% and 91\% in SMWUF and SMWDF, respectively, when compared with SMW, presenting statistical difference between the samples $(\mathrm{p}<0.05)$. This indicates that in the DF process occurs the passage of lactose through the membrane due to its size and successive washes. The $10 \mathrm{kDa}$ membrane used in this work, because it has a molecular weight of cut above the molecular weight of lactose of $342 \mathrm{Da}$, should not retain lactose, however the formation of gel layer on the membrane surface and the fouling can interfere in the selectivity of the membrane $[14,19]$.

A progressive increase of protein content with the UF and DF process was observed in relation to SMW, differing statistically from each other $(\mathrm{p}<0.05)$. In the UF process the protein was double in relation to SMW, as well as DF to UF. The milk whey proteins concentration is due to the membrane pore size $(10 \mathrm{kDa}$ or $0.2 \mu \mathrm{m})$ and the formation of gel layer on the membrane.The size of milk whey proteins, in general, ranged between $14 \mathrm{kDa}(\alpha-\mathrm{LA})$ and $1000 \mathrm{kDa}(\mathrm{Ig})[20]$ remaining retained on the membrane. As the protein in SMWDF was greater than $80 \%$, the product could be considered a whey protein concentrate (WPC80).

Figure 2 shows the electrophoretic profile between $10 \mathrm{kDa}$ and $200 \mathrm{kDa}$ of SMW and the concentrated by UF (SMWUF) and DF (SMWDF). The SMW, SMWUF and SMWDF samples showed a strong signal for $\beta$ - $\mathrm{Lg}(18 \mathrm{kDa})$ and $\alpha-\mathrm{La}(14 \mathrm{kDa})$, and less intense for serum albumin $(69 \mathrm{kDa})$, which are characteristic of these proteins [21]. Other signals were observed between the $25 \mathrm{kDa}$ and $85 \mathrm{kDa}$. According to Antunes (2003) [22] these bands may indicate the presence of immunoglobulins of light fraction $(25 \mathrm{kDa})$ and of heavy fraction $(50 \mathrm{kDa})$, weak signals suggest small concentrations of lactoperoxidase $(78 \mathrm{kDa})$ and lactoferrin $(76 \mathrm{kDa})$. Hernández-Ledesma et al. (2011) [23], assert that $\beta$-Lg, $\alpha$-La and serum albumin are the major milk whey proteins.

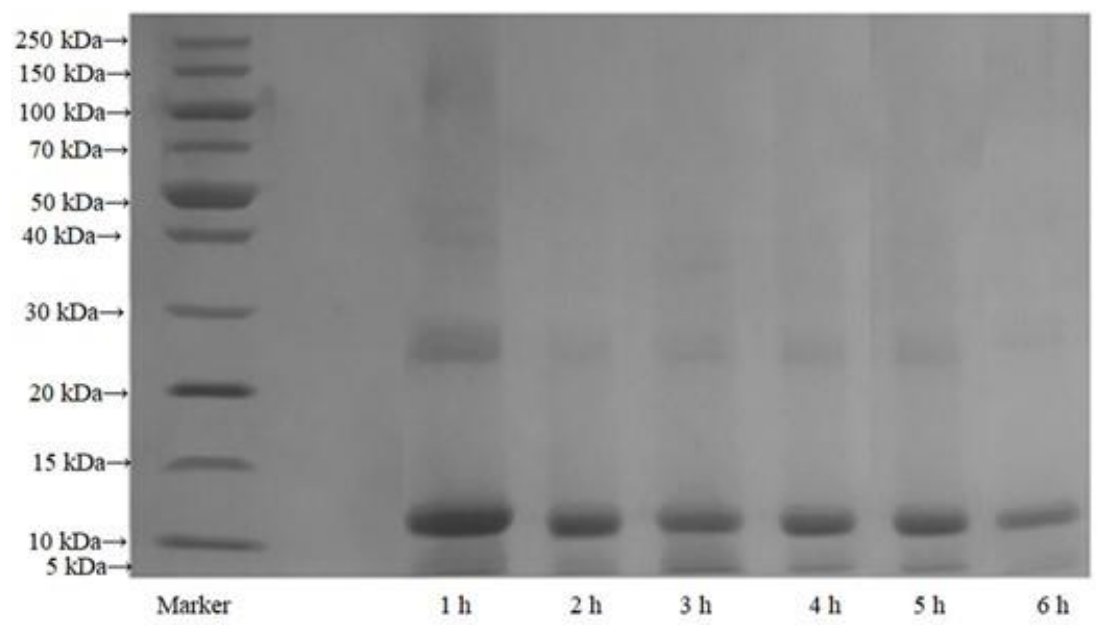

Figure 2: Electrophoretic profile in SDS-PAGE profile between $10 \mathrm{kDa}$ and $200 \mathrm{kDa}$ of SMW and the concentrated by UF (SMWUF) and DF (SMWDF).

The presence of different proteins is extremely important in protein concentrates because they have different functionalities: $\beta$-Lg have gelatinizing properties, while $\alpha$-La contributes to the formation of foam. They may also show bacteriostatic properties by lactoferrin and lactoperoxidase. 
Table 2 presents the degree of hydrolysis and the minimal bactericide concentration performed by the SMWDF (solution 10\% w/v) in different hydrolysis times on gram-positive and gramnegative bacteria. A gradual increase in the degree of hydrolysis up to $5 \mathrm{~h}$ of reaction is observed, with statistical difference $(\mathrm{p}<0.05)$ between the times. After $5 \mathrm{~h}$ of reaction, there was no statistical difference ( $p>0.05)$, being this, the reaction time with the highest degree of hydrolysis.

Table 2: Degree of hydrolysis and minimal bactericide concentration of hydrolyzate of SMWDF obtained by the action of protease (corolase $\mathrm{H}-\mathrm{pH}$ ) in different times.

\begin{tabular}{cccc}
\hline \multirow{2}{*}{ Time (h) } & Degree of hydrolysis $(\%)$ & \multicolumn{2}{c}{ Minimum bactericidal concentration $(\boldsymbol{\mu g} / \mathbf{m L})$} \\
\cline { 3 - 4 } & & Salmonella choleraesuis & Listeria monocytogenes \\
\hline 1 & $12.07^{\mathrm{e}} \pm 0.06$ & $5.0^{\mathrm{e}} \pm 0.02$ & $12.5^{\mathrm{c}} \pm 0.04$ \\
2 & $13.03^{\mathrm{d}} \pm 0.06$ & $5.0^{\mathrm{e}} \pm 0.01$ & $15.0^{\mathrm{b}} \pm 0.07$ \\
3 & $14.06^{\mathrm{c}} \pm 0.05$ & $7.5^{\mathrm{d}} \pm 0.01$ & $15.0^{\mathrm{b}} \pm 0.06$ \\
4 & $15.18^{\mathrm{b}} \pm 0.07$ & $10.0^{\mathrm{c}} \pm 0.04$ & $19.9^{\mathrm{a}} \pm 0.08$ \\
5 & $15.55^{\mathrm{a}} \pm 0.01$ & $12.5^{\mathrm{b}} \pm 0.06$ & $20.1^{\mathrm{a}} \pm 0.07$ \\
6 & $15.56^{\mathrm{a}} \pm 0.01$ & $15.0^{\mathrm{a}} \pm 0.06$ & $20.0^{\mathrm{a}} \pm 0.10$ \\
\hline
\end{tabular}

Means ( \pm standard deviations) followed by same letters on the column, represents no significant difference at $5 \%$ level (Tukey test).

The degree of hydrolysis values remained between 12.07 and $15.55 \%$, differing statistically $(\mathrm{p}<0.05)$ up to $5 \mathrm{~h}$ of reaction. For Adjonu et al. (2013) [24], the degree of hydrolysis depends on the enzyme, since each one has its specificity. The minimum inhibitory concentration (MIC) evaluated in the present study is inversely proportional to the halos measurement and refers to the lowest concentration $(\mathrm{mg} \mathrm{mL}-1)$ or percentage $(\%)$ of the hydrolyzate capable of inhibiting the bacterium. Thus, the smaller the MIC, the greater the area of the halo and the better antibiotic potential. The samples of SMWDF in the different times of hydrolysis presented antimicrobial activity, against $S$. choleraesuise and L. monocytogenes. In all times, the Gram-negative bacterial strains were more sensitive in comparison to Gram-positive strains.

Among all hydrolysis times, the highest inhibition for both bacteria was reached in $1 \mathrm{~h}$. The same minimum bactericidal concentration for $S$. choleraesuis was obtained in $1 \mathrm{~h}$ and $2 \mathrm{~h}$ of hydrolysis, not statistically differing $(\mathrm{p}>0.05)$, however, for L. monocytogenes a low minimum bactericidal concentration was observed from 1 to $2 \mathrm{~h}$. The hydrolyzates of 4,5 and $6 \mathrm{~h}$ did not present statistical difference ( $>00.05$ ) against L. Monocytogenes. At 3, 4 and $5 \mathrm{~h}$ of hydrolysis was required high amount of hydrolysates samples for inhibition of S. choleraesuis. This difference may be associated to the action mechanism of proteins, and of peptides generated against inhibition of bacteria [25].

Among the proteins present in the SMWDF, is observed by the electrophoretic profile of the hydrolyzates, that possibly $\beta-\mathrm{Lg}, \alpha-\mathrm{La}$ and lactoferrin were hydrolyzed. The two investigated bacteria were controlled with the hydrolyzate sample, which could be suggestive of the release of bioactive peptides. The results of the protein fractions of hydrolyzate samples $(1,2,3,4,5$, and 6 h) from the SMWDF are shown in Figure 3. 


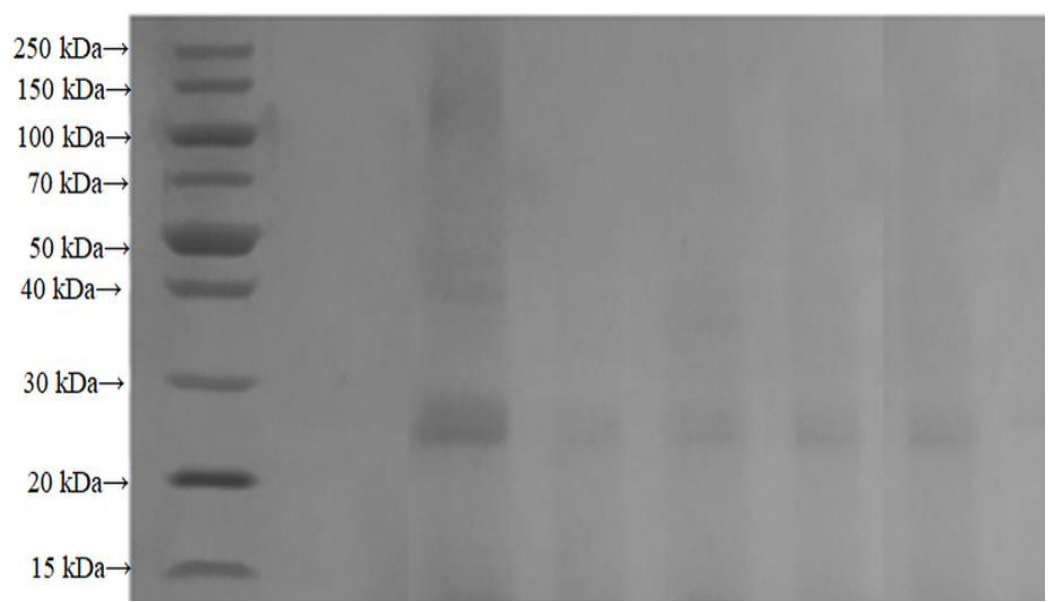

Figure 3: Electrophoretic profile in SDS-PAGE for molecular weight marker and hydrolyzate samples in different times $(1,2,3,4,5$ and $6 h)$.

The lowest detected band was $5 \mathrm{kDa}$, signaled for all the hydrolyzate, losing the intensity in $6 \mathrm{~h}$ of hydrolysis. A higher intensity band was observed at $10 \mathrm{kDa}$ at all times. Lower intensity signals were observed between the 20 and $30 \mathrm{kDa}$ band in $1 \mathrm{~h}$ of hydrolysis, which indicate the presence of immunoglobulins of light fraction $(25 \mathrm{kDa})$. This signal lost its intensity from $2 \mathrm{~h}$ of hydrolysis, which could suggest the protein hydrolysis, since, the degree of hydrolysis also increased in relation to the time of $1 \mathrm{~h}$ from $12.07 \%$ to $13.03 \%$.

Before hydrolysis, SMWDF showed signal of serum albumin $(69 \mathrm{kDa})$, and immunoglobulins $(25$ to $50 \mathrm{kDa})$, lactoferrin $(76 \mathrm{kDa})$ and lactoperoxidase $(78 \mathrm{kDa})$ (Figure 2). However, after hydrolysis the samples showed bands at lower molar mass, with $5 \mathrm{kDa}, 10 \mathrm{kDa}$, and between 20 $\mathrm{kDa}$ and $30 \mathrm{kDa}$, indicating that the proteins previously present were hydrolyzate by the enzyme into smaller peptides. In $1 \mathrm{~h}$ of hydrolysis both $\alpha$-La $(14 \mathrm{kDa})$ and $\beta$-Lg (18 kDa) were not detectable in the electrophoresis gel, suggesting that both were completely hydrolyzate by the enzyme.

In Table 3 are presented the results of the antioxidant activity at the different times of hydrolysis $(1,2,3,4,5$ and $6 \mathrm{~h})$ from the SMWDF in the range of hydrolyzate concentrations between 0.5 to $3.0 \mathrm{mg} / \mathrm{mL}$. An increase in antioxidant activity was observed with hydrolysis time and with hydrolysis concentration. The highest antioxidant activity was observed at the maximum concentration tested $(3.0 \mathrm{mg} / \mathrm{mL})$ and at the time of $6 \mathrm{~h}$ of hydrolysis, differing statistically $(\mathrm{p}<0.05)$ from the other concentrations.

Table 3: Antioxidant activity of protease (corolase H-pH) in DF sheep whey proteins obtained in different concentrations of hydrolyzates in relation to reaction time

\begin{tabular}{ccccccc}
\hline $\begin{array}{c}\text { Concentration of } \\
\text { hydrolyzate } \\
(\mathbf{m g} / \mathbf{m L})\end{array}$ & \multicolumn{5}{c}{ Antioxidant activity (\%) } \\
\cline { 2 - 6 } & $\mathbf{1}$ & $\mathbf{2}$ & $\mathbf{3}$ & $\mathbf{4}$ & $\mathbf{5}$ & $\mathbf{6}$ \\
\cline { 2 - 6 } & $8.29^{\mathrm{Fe}}$ & $10.14^{\mathrm{Fd}}$ & $12.33^{\mathrm{Fc}}$ & $13.46^{\mathrm{Fb}}$ & $13.96^{\mathrm{Fa}}$ & $14.09^{\mathrm{Fa}}$ \\
& \pm .5 & \pm 0.15 & \pm 0.11 & \pm 0.13 & \pm 0.09 & \pm 0.10 \\
& $29.02^{\mathrm{Ed}}$ & $31.83^{\mathrm{Ec}}$ & $33.11^{\mathrm{Eb}}$ & $34.54^{\mathrm{Ea}}$ & $34.75^{\mathrm{Ea}}$ & $34.71^{\mathrm{Ea}}$ \\
1.0 & \pm 0.26 & \pm 0.24 & \pm 0.20 & \pm 0.20 & \pm 0.15 & \pm 0.20 \\
& $58.28^{\mathrm{Df}}$ & $59.00^{\mathrm{De}}$ & $60.64^{\mathrm{Dd}}$ & $61.79^{\mathrm{Dc}}$ & $63.03^{\mathrm{Db}}$ & $63.91^{\mathrm{Da}}$ \\
1.5 & \pm 0.33 & \pm 0.35 & \pm 0.30 & \pm 0.29 & \pm 0.31 & \pm 0.26 \\
& $69.44^{\mathrm{Ce}}$ & $71.32^{\mathrm{Cd}}$ & $72.48^{\mathrm{Cc}}$ & $74.22^{\mathrm{Cb}}$ & $75.51^{\mathrm{Ca}}$ & $75.93^{\mathrm{Ca}}$ \\
2.0 & \pm 0.39 & \pm 0.42 & \pm 0.40 & \pm 0.38 & \pm 0.41 & \pm 0.45 \\
& $76.90^{\mathrm{Be}}$ & $78.12^{\mathrm{Bd}}$ & $80.27^{\mathrm{Bc}}$ & $81.16^{\mathrm{Bb}}$ & $82.18^{\mathrm{Ba}}$ & $82.47^{\mathrm{Bba}}$ \\
2.5 & \pm 0.26 & \pm 0.48 & \pm 0.50 & \pm 0.52 & \pm 0.55 & \pm 0.56 \\
& $80.85^{\mathrm{Ae}}$ & $83.88^{\mathrm{Ad}}$ & $85.37^{\mathrm{Ac}}$ & $87.57^{\mathrm{Ab}}$ & $88.62^{\mathrm{Aa}}$ & $88.75^{\mathrm{Aa}}$ \\
3.0 & \pm 0.60 & \pm 0.55 & \pm 0.62 & \pm 0.56 & \pm 0.30 & \pm 0.55 \\
\hline
\end{tabular}

Means ( \pm standard deviations) followed by same uppercase letters on the column and same lowercase letters on the lines, represents no significant difference at $5 \%$ level (Tukey test). 
Corrêa et al. (2014) [26] by hydrolyzing aqueous solutions of sheep's milk whey (10g/L) for 6 h using Bacillus sp. P7 observed that the longer the hydrolysis time, the higher the antioxidant activity. Same development observed in the present work.

The IC 50 values found for hydrolyzate ranged from 1.32 to $1.56 \mathrm{mg} / \mathrm{mL}$. The lower the IC 50 value the greater the antioxidant activity of the sample. Therefore, the time of $1 \mathrm{~h}$ of hydrolysis was responsible for the lower value generated for the antioxidant activity, followed by the time of 3 and $5 \mathrm{~h}$.

This increase in antioxidant activity may be associated with enzymatic hydrolysis, as highlighted by Dryáková et al. (2010) [27] the bioactivity of intact proteins has shown improvements after being hydrolyzate by enzymes. The oscillations in the antioxidant activity may be associated to the peptide structure or the presence of amino acids (Hernández-Ledesma et al. 2005). According to Corrêa et al. (2014) [26] the bioactivities of protein hydrolyzate are largely dependent on the enzymes used and also on the protein to be hydrolyzed.

\section{CONCLUSION}

The UF process associated to the DF process in 10kDa membrane in the concentration of sheep's milk whey increased the total protein content by two times.

The antimicrobial activity against Gram-negative bacteria; Salmonella choleraesuis, and for Gram positive bacteria; Listeria monocytogenes was observed at all times of hydrolysis. All analyzed samples controlled more effectively $S$. choleraesuis. The reaction time of $1 \mathrm{~h}$ had lower values of minimum inhibitory concentration against the two bacteria evaluated.

The highest antioxidant activity was observed at the maximum concentration tested and at the time of $6 \mathrm{~h}$ of hydrolysis. The antioxidant activity was higher in the higher times of hydrolysis and higher concentration of hydrolyzate. However, the lowest hydrolysate concentration required to capture $50 \%$ (IC50) was in $1 \mathrm{~h}$ of hydrolysis.

Sheep's milk whey showed potential for application in food products of interest, through SMWDF (10\% (w/v) at $\left.60{ }^{\circ} \mathrm{C}, \mathrm{pH} 8.0\right)$ hydrolyzate with the enzyme corolase $\mathrm{H}-\mathrm{pH}(1 \%$ based on protein content), where the reaction time of $1 \mathrm{~h}$ hydrolysis is enough to present antimicrobial and antioxidant activity against $S$. choleraesuis and $L$. monocytogenes.

\section{ACKNOWLEDGEMENTS}

The authors thank to National Council for Scientific and Technological Development (CNPq), Coordination for the Improvement of Higher Education Personnel (CAPES - Finance Code 001) and Research Support Foundation of the State of Rio Grande do Sul (FAPERGS).

\section{REFERENCES}

1. Pagno CH, Baldasso C, Tessaro IC, Flores SH, Jong EV. Obtaining milk whey protein concentrates and characterizing their technological functional properties. Rev Aliment Nutr. 2009 Apr/Jun;20(2):231-239.

2. Wang X, Zhao X, Huang D, Pan X, Qi Y, Yang Y, Zhao H, Cheng G. Proteomic analysis and cross species comparison of casein fractions from the milk of dairy animals. Sci Rep. 2017 Feb;7:1-9, doi:10.1038/srep43020.

3. Baldasso C, Barros TC, Tessaro IC. Concentration and purification of whey proteins by ultrafiltration. Desalination. 2011 Sep;278(1-3):381-386, doi:10.1016/j.desal.2011.05.055.

4. Belhamidi D, Larif M, Achatei A, Habziz S, Zouhri N, Rafiq M, Selma Chouni S, Elhannouni F, Elmidaoui A. Recovery and purification of whey with the concentration, reincorporation and reuse Protein and Lactose. J Mats Environ Sci. 2015;6:861-868.

5. Yee KWK, Wiley DE, Bao J. Whey protein concentrate production by continuous ultrafiltration: operability under constant operating conditions. J Membrane Sci. 2007 Mar;290(1-2):125-137, doi:10.1016/j.memsci.2006.12.026.

6. Miller GL. Use of dinitrosalicylic acid reagent for determination of reducing sugar. Anal Chem. 1959;31(3):426-428, doi: 10.1021/ac60147a030 
7. Hoyle NT, Merritt JH. Quality of fish protein hydrolysates from herring (Clupeaharengus). J Food Sci. 1994 59:76-79, doi: 10.1111/j.1365-2621.1994.tb06901.x.

8. Lowry OH, Rosebrough NF, Farr AL, Randall RJ. Protein measurement with the Folin phenol reagent. J Biol Chem. 1951 193:265-275.

9. Association of Official Analytical Chemistry (AOAC). Official methods of analysis of the Association of Official Analytical Chemists 18. ed. Washington: AOAC; 2007. 3000 p.

10. International Dairy Federation. IDF - FIL 5 - B: Cheese and processed cheese products: Determination of fat content gravimetric method (reference method); $1986.7 \mathrm{p}$.

11. Laemmli UK. Cleavage of structural proteins during the assembly of the head of bacteriophage T4. Nature. 1970227:680-685.

12. Monge A, Ganellin CR, editor. Practical studies for medicinal chemistry. Geneva (Switzerland): IUPAC, 2006. p. 1-14.

13. Smith-Palmer A, Stewart J, Fyfe L. Antimicrobial properties of plant essential oils and essences against five important food-borne pathogens. Lett Appl Microbiol. 1998 Feb;26(2):118-122, doi:10.1046/j.1472765X.1998.00303.x.

14. Iltchenco S, Preci D, Bonifacino C, Fraguas EF, Steffens C, Panizzolo LA, Colet R, Fernandes IA, Abirached C, Valduga E, Steffens J. Whey protein concentration by ultrafiltration and study of functional properties. Ciênc Rural. 2018 Jun;48(5):e20170807, doi:10.1590/0103-8478cr20170807.

15. Rice GS, Kentish SE, O Connor AJ, Barbeiro AR, Pihlajamaki A, Nystrom M, Stevens GW. Analysis of separation and fouling behaviour during nanofiltration of dairy ultrafiltration permeates. Desalination. 2009 Jan;236(1-3):23-29, doi:10.1016/j.desal.2007.10.046.

16. Brasil. Ministério da Agricultura, Pecuária e Abastecimento, Secretaria de Defesa Agropecuária. Portaria $\mathrm{n}^{\circ}$ 53, de 10 de abril de 2013. Dispõe sobre padrões de identidade e qualidade de soro de leite. Diário Oficial da União. 2013 Abr 11;69(Seção 1):6.

17. García-Pérez F J, Lario Y, Fernández-López J, Sayas E, Pérez-Alvarez JA, Sendra E. Effect of orange fiber addition on yogurt colour during fermentation and cold storage. Color Res Appl. 2005 Dec;30(6): 457-463, doi: 10.1002/col.20158

18. Azevedo VM, Costa ALR, Fukushima KL, Borges SV. Mechanical and optical barrier properties of whey protein concentrate films. Rev Instituto Laticínios Cândido Tostes. 2014 Jul/Aug;69(4):237-247, doi:10.14295/2238-6416.v69i4.307.

19. Brans G, Shroen CGPH, Vander Sman RGM, Boom RM. Membrane fractionation of milk: state of the art and challenge. J Membrane Sci. 2004 Nov;243(1-2):263-272, doi:10.1016/j.memsci.2004.06.029.

20. Wal JM. Bovine milk allergenicity. Ann Allergy Asthma Immunol. 2004 Nov;93(3):2-11, doi:10.1016/S1081-1206(10)61726-7.

21. Thompson A, Boland M, Singh H. Milk protein: from expression to food. New Zealand: Massey University; 2009. 561 p.

22. Antunes AJ. Functionality of bovine whey proteins. São Paulo (SP): Manole Ltda; 2003. 135 p.

23. Hernández-Ledesma B, Ramos M, Gomez-Ruiz JA. Bioactive components of ovine and caprine cheese whey. Small Ruminant Res. 2011 Nov;101(1-3):196-204, doi:10.1016/j.smallrumres.2011.09.040.

24. Adjonu R, Doran G, Torley PE, Agboola S. Screening of whey protein isolate hydrolysates for their dual functionality: influence of heat pre-treatment and enzyme specificity. Food Chem. 2013 Feb;136(34):1435-1443, doi:10.1016/j.foodchem.2012.09.053.

25. Minervini F, Algaron F, Rizzelli CG, Fox PF, Monnet V, Gobbetti M. Agiotensin I-converting-enzymeinhibitory and antibacterial peptides from Lactobacillus helveticus PR4 proteinase-hydrolyzed caseins of milk from six species. Americ Society Microbiol. 2003 Sep;69(9):5297-5305, doi:10.1128/AEM.69.9.5297-5305.2003.

26. Corrêa APF, Daroit DJ, Fontoura R, Meira SMM, Segalin J, Brandelli A. Hydrolysates of sheep cheese whey as a source of bioactive peptides with antioxidant and angiotensin-converting enzyme inhibitory activities. Peptides. 2014 Nov;61(2014):48-55, doi:10.1016/j.peptides.2014.09.001.

27. Dryáková A, Pihlanto A, Marnila P, Curda L, Korhonen HJT. Antioxidant properties of whey protein hydrolysates as measured by three methods. Eur Food Res Technol. 2010 Apri;230(6):865-874, doi: 10.1007/s00217-010-1231-9. 